\title{
PENGARUH MEROKOK TERHADAP FUNGSI EREKSI PRIA
}

\author{
${ }^{1}$ Nurbaiti M. S. Hasan \\ ${ }^{2}$ LydiaTendean \\ ${ }^{2}$ Benny Wantouw
${ }^{1}$ Kandidat Skripsi FakultasKedokteranUniversitas Sam Ratulangi Manado
${ }^{2}$ Bagian Biologi Fakultas Kedoteran Universitas Sam Ratulangi Manado
Email: ViviAnvi68@gmail.com

\begin{abstract}
Every year in Indonesia 199 billion cigarettes were consumed, caused 5 million people died. If this event can't be prevent, the mortality rate will be increase in twice closed to 10 million people each year in 2020. Smoking can make a lot of health problem, include erectile dysfunction. The aim of this study is to find out the effect of smoking on male's erectile function. This is a descriptive observation study that was conducted in Malalayang Station, District Malalayang, Manado City. There were 50 males who participated in this study. Erectile function was assessed using IIEF-5 (International Index of Erectile Function-5). This study shows that most of the 50 men who participated in this study reported a disfunction in erectile function. As much as $2 \%$ men had severe dysfunction, 33\% have moderate dysfunction, 38\% have mild to moderate dysfunction, and 38\% have mild dysfunction. Based on our findings, we concluded that smoking affects the incidence of erectile dysfunction.
\end{abstract}

Keywords: cigarette, erectile dysfunction.

\begin{abstract}
Abstrak :Konsumsi rokok Indonesia setiap tahun mencapai 199 milia rbatang rokok, akibatnya terjadi kematian 5 juta orang pertahunnya, bila hal ini tidak dapat dicegah maka jumlah kematian akan meningkat 2 kali mendekati 10 juta orang pertahun pada Merokok dapat menyebabkan berbagai gangguan kesehatan salah satunya adalah disfungs iereksi. Tujuan penelitian ini adalah untuk mengetahu ipengaruh merokok terhadap fungsi ereksi pria. Penelitiaan dilakukan di Terminal Malalayang, Kecamatan Malalayang, Kota Manado dengan jumlah sampel 50 orang perokok. Penelitian ini merupakan jenis penelitian observasional deskriptif. Fungsi ereksi dapat dinilai dengan menggunakan kuesioner IIEF-5 (International Index of Erectile Function).Penelitian ini menunjukan bahwa dari 50 pria perokok seluruhnya mengalami disfungsi ereksi, yaitu pria dengan disfungsi ereksi berat $2 \%$, disfungsi ereksi sedang 33\%, disfungsi ereksi sedang-ringan 38\%, dan disfungsi ereksi ringan 38\%. Dari hasil penelitian ini dapat disimpulkan bahwa merokok berpengaruh terhadap terjadinya disfungsi ereksi pria.
\end{abstract}

Kata kunci: rokok, disfungsi ereksi.

Disfungsi erekesi merupakan ketidak mampuan berulang pada pria dalam mencapai dan mempertahankan ereksi yang cukup untuk melakukan hubungan seksual, Badan Kesehatan Dunia (WHO) mendefinisikan disfungsi ereksi sebagai gangguan ereksi yang terjadi selama minimal 3 bulan $^{1}$. 
Rokok adalah hasil olahan tembakau terbungkus yang meliputi kretek dan rokok putih yang dihasilkan dari tanaman Nicotiana Tabacum, Nicotiana Rustica dan spesies lainnya atau sintetisnya yang mengandung nikotin dan tar dengan atau tanpa bahan tambahan. ${ }^{2}$ Terdapat 13 unsur terkandung dalam tembakau, filter bersih, kertasrokok, putung, abu rokok dan filter setelah dihisap, yaitu : $\mathrm{Na}, \mathrm{K}$, $\mathrm{Br}, \mathrm{Co}, \mathrm{Cr}, \mathrm{Sr}, \mathrm{Ta}, \mathrm{Cs}, \mathrm{La}, \mathrm{Au}, \mathrm{Fe}, \mathrm{Scdan}$ Zn. ${ }^{3}$ Indonesia menduduki peringkat ke-4 jumlah perokok terbanyak di dunia dengan jumlah sekitar 141 juta orang. Diperkirakan, konsumsi rokok Indonesia setiap tahun mencapai 199 miliar batang rokok. Akibatnya adalah kematian sebanyak 5 juta orang pertahunnya. Bila hal ini tidak dapat dicegah, maka jumlah kematian akan meningkat dua kali mendekati 10 juta orang pertahun pada tahun 2020. ${ }^{4}$

Kadang ereksi tidak dapat terjadi bila darah tidak mengalir bebas ke penis. Merokok dapat merusak pembuluh darah, nikotin menyempitkan arteri yang menuju penis, mengurangi aliran darah dan tekanan darah menuju penis. Efek ini meningkat bersamaan dengan waktu. Masalah ereksi ini merupakan peringatan awal bahwa tembakau telah merusak area lain dari tubuh. ${ }^{4}$

\section{METODE PENELITIAN}

Tujuan penelitian ini ialah untuk mengetahui pengaruh rokok terhadap terjadinya disfungsi ereksi serta mekanismenya. Penelitian ini diharapkan dapat memberikan manfaat antara lain berupa :

1. Memberikan informasi kepada masyarakat tentang disfungsi ereksi akibat merokok.

2. Memberikan informasi dasar yang berguna untuk penelitian lebih lanjut.

Jenis penelitian yang digunakan adalah penelitian observasional deskriptif

\section{Tempat dan Waktu Penelitian}

Penelitian dilaksanakan di Kecamatan Malalayang, terminal malalayang pada bulan November 2013 - Januari 2014. Dalam penelitian ini diambil populasi yaitu pada pria dengan kebiasaan merokok aktif yang berada di kota manado yaitu pada supir angkutan umum di terminal malalayang yang berjumlah keseluruhan 197. Untuk sampel penelitian dapat diketahui dari jumlah populasi dan di dapatkan jumlah sampel dengan menggunakan rumus solvin. Jadi sampel yang menjadi perwakilan dalam penelitian dari seluruh populasi adalah 66 responden dengan menggunakan tehnik purposive sampling berdasarkan pertimbangan tertentu oleh peneliti.

Penelitian ini menggunakan kuesioner terstandar yaitu International Index of Erectile Function (IIEF-5). Tujuan IIEF adalah untuk mengetahui kondisi ereksi penderita, apakah termasuk dalam kategori disfugsi ereksi berat, sedang, atau ringan.

\section{HASIL PENELITIAN}

Distribusi perokok menurut hasil perihitungan skor IIEF berdasarkan kelompok usia.

Fungsi Ereksi

Responden

\begin{tabular}{lccccc} 
& & & & & \\
& $30-40$ & $41-50$ & $51-60$ & $\mathrm{~N}$ & $\%$ \\
\hline a. Normal & 0 & 0 & 0 & 0 & 0 \\
b. DE Ringan & 14 & 5 & 0 & 19 & 38 \\
c. DE Sedang-ringan & 6 & 6 & 7 & 19 & 38 \\
& & & & & \\
d. DE Sedang & 2 & 4 & 5 & 11 & 22 \\
$\quad$ e. DE Berat & 0 & 1 & 0 & 1 & 2 \\
\hline & & & & & \\
Total & 22 & 16 & 12 & 50 & 100 \\
\hline
\end{tabular}

Keterangan: Normal= tidak disfungsi ereksi, DE Ringan= disfungsi ereki ringan $(>50 \%)$, DE Sedang-ringan= disfungsi ereksi sedang-ringan (=5\%), DE Sedang= disfungsi ereksi sedang $(<50 \%)$, DE Berat= disfungsi ereksi berat. 
Secara keseluruhan penelitian pada Pria dengan kebiasaan merokok yang berpengaruh terhadap fungsi ereksi, didapat kan seluruh responden mengalami disfungsi ereksi dan dengan tingkatan atau stadium yang berbeda-beda yang dijabarkan pada table diatas, didapatkan distribusi perokok menurut hasil perhitungan skor Indeks Internasional Fungsi Ereksi (IIEF-5), berdasarkan kelompok usia, yaitu Normal sebanyk 0 orang (0\%), Disfungsi ereksi ringan sebanyak 19 orang (38\%), Disfungsi ereksi sedang-ringan 19 orang (38\%), Disfungsi sedang 11 orang (33\%), dan Disfungsi berat 1 orang (2\%). Hasil olah data table diatas berkaitan dengan fakta pada beberapa penelitian yang menyatakan bahwa pria yang memiliki kebiasaan merokok satu pak rokok/hari beresiko 40\% lebih tinggi menderita disfungsi ereksi dari pada pria yang tidak merokok. Dari jurnal Tabacco Control mempublikasikan sebuah penelitian terbaru pada 8000 pria Australia berumur 16-59 tahun yang merokok satu pak/hari beresiko 24\% lebih tinggi menderita gangguan ereksi. Dan semakin banyak mereka merokok maka presentase resikonya juga meningkat. Para pria yang merokok lebih dari 20 batang/hari mengalami peningkatan resiko disfungsi ereksi sebesar $39 \%{ }^{6}$

Penelitian lain yang di publikasikan oleh American Journal of Epidemiology menunjukan bahwa pada pria perokok berusia 40 tahun lebih sering mengalami gangguan ereksi dari pada pada pria yang berusia lebih tua namun tidak merokok. Bahkan resikonya sampai dua kali lipat pada pria perokok berusia 40 tahun dibandingkan pada pria berusia 50 tahun yang tidak merokok. Dr. Larry Lipshultz, kepala pengobatan reproduks pria di Baylor Collage of Medicine di Houston AS, menjelaskan bahwa kebiasaan merokok menyebabkan penyempitan pembuluh darahs ehingga merupakan penyebab utama disfungsi ereksi selain obesitas, konsumsi alcohol berlebihan, dan penyalahgunaan narkoba. ${ }^{6}$
Melalui mekanisme diatas maka dapat dilihat bahwa pria dengan kebiasaan merokok memiliki resiko lebih tinggi untuk mengalami disfungsi ereksi.

\section{SIMPULAN}

Dari hasil penelitian daspat disimpulkan:

1. Merokok berpengaruh terhadap fungsi ereksi pada pria.

2. Penurunan fungsi ereksi pada pria perokok di akibatkan oleh :kandungan zat nikotin dalam rokok yang mengakibatkan penyempitan pembuluh darah, membuat suplai darah ke seluruh organ menjadi berkurang atau tidak optimal sehingga dapat terjadi disfungsi ereksi.

\section{SARAN}

1. Perlu dilakukan penelitian lanjutan dengan pemeriksaan skrining awal yang lebih lengkap sehingga factor lain yang menyebabkan disfungsi ereksi pada pria dapat dikendalikan.

2. Untuk skrining disfungsi ereksi seksual pria sebaiknya selain dengan menggunakan kuesioner dapat dilengkapi dengan pemeriksaan laboratorium kadar testosterone darah.

3. Perlu dilakukan penelitian dengan jumlah sampel yang lebih banyak dan prosedur penelitian yang lebihlengkap, agar didapatkan data dengan cakupan populasi lebih besardan data yang lebihlengkap.

\section{DAFTAR PUSTAKA}

1. Heffner $\mathbf{L} \mathbf{J}$, Schust $\mathbf{D}$ J. At a glance sistem reproduksi. Alih bahasa, Vidhia Umami. Editor, Amalia Safitri. Edisi Dua. Jakarta; EMS; 2006. Hal 74.

2. Keputusan menteri perindustrian dan perdagangan RI. Pedoman cara uji kandugan kadar nikotin dan tar rokok. No 62/ MPP/ Kep/ 2. 2004

3. Mulyaningsih R. Penentuan unsur logam dan distribusinya dalam komponen rokok dengan metode $\mathrm{K}_{0}$-Analisis aktivasi neutron Instrumental. Pusat teknologi bahan dan industri nukli. 
Hasan, Tandean, Wantouw: Pengaruh merokok terhadap...

2009. BATAN

4. Gondodiputro S. Bahaya tembakau dan bentuk - bentuk sediaan tembakau. Unpad: fakultas kedokteran; bagian ikmas. 2007. Bandung

5. Pasaribu R. Rumus slovin. Wordpress; 2013. Available from:

http://rowlandpasaribu.files.wordpres s.com/2013/03/06-populasi-dansampel.pdf

6. Anggarda. Rokok, kolestrol dan impotensi. [Diakses] 30 november 2009. Available from: http://anggarda.wordpress.com/2009/ 11/30/rokok-kolestrol-danimpotensi. 